\title{
Rotational Presidency And Political Corruption In Nigeria: A Critical Evaluation Of President Obasanjo And Umoru Musa Yar'Adua's Regime, 1999-2010
}

\author{
Dr. Okwudili Chukwuma Nwosu, Emmanuel Ugwuerua, \\ Provost, The College of Education, Nsukka, Enugu State, Nigeria \\ Director, The College of Education, Nsukka, Enugu State, Nigeria
}

\begin{abstract}
This article examines whether rotational Presidency has contributed towards reducing political corruption in Nigeria during the regimes of President Olusegun Obasanjo from 1999 to 2007 and President Umoru Musa Yar'Adua from 2007 to 2010. The article notes that political corruption was not reduced by rotational Presidency. Political corruption was at its highest ebb during the regimes under study. The paper contends that Nigeria's democracy especially the one that commenced from May 29, 1999 was born with persistent political corruption. The article suggested that a lot need to be done by the anti-corruption agencies like the Economic and Financial Crime Commission (EFCC) and the Independent and Corrupt Practices Commission (ICPC). They should intensify their efforts and do their jobs without fear of favour, and people of proven integrity should always be appointed at the helm of affairs of these commissions, without any form of interference from the government of the day.
\end{abstract}

Key Words: Rotational, Rotational Presidency, Political Corruption in Nigeria, President Obasanjo regime, President Yar'Adua's Regime, 1999 Constitution, People's Democratic Party

\section{Introduction}

The origin of rotational Presidency is very much unknown, it can be described to be as old as man's existence in the universe. Records show that the system of rotation was practiced by the Greeks and the ancient Roman Empire. [1] The European Union and Switzerland, also practice a rotational system of government. The presidency of the European Union rotates among the member states while it rotates among the various ethnic groups in Switzerland. Switzerland and the European Union are among the most stable country and institution in the world. Thus, Switzerland and the European Union are very good examples where rotational system are functionally applied along ethnic and national lines. [2]

The idea of rotational Presidency started in Nigeria during the 1995 National Constitutional Conference under the regime of former Nigerian Maximum ruler, late President Sani Abacha. Six geo-political zones were adopted during the conference and the National Political Offices will be filled by candidates on a rotational basis based on the six geo-political zones with a transitional provision of 30 years. It was agreed that the rotational system was to be entrenched in the then Draft Constitution and will be applied to all spheres of government. [3] The six geo-political zones which includes the North East, North West and North Central in the northern part of the country and the South East, South West and South South in the southern part of the country was introduced as a remedy to the issue of marginalization in Nigeria. It was assumed that the six geo-political zones will bring to an end the issue of monopoly of power by the north.

The northern part of the country had dominated the leadership of Nigeria, and they use this position to secure juicy political privileges for their own people at the detriment of the people from the south of the country. This sad experience was climaxed in the annulment of the June 12, 1993 presidential election.[4] The election was won by late Moshood Abiola, a southerner.

Rotational presidency in Nigeria implies that the office of the President was to be rotated evenly among the six geo-political zones of the nation. [5] That was why during the 1999 general election, President Olusegun Obasanjo contested under the auspices of the Peoples Democratic Party and Olu Falae vied for All Nigerian Peoples Party, thus, two South Westerners contested the presidential slot. The lacuna in the rotational principle was felt immediately after the expiration of President Olusegun Obasanjo's four years term, he initiated plans for a second term in office, which was not mentioned in the agreement on rotational Presidency, this generated a lot of controversy. The Northerners insisted that power was going to return to them while the Southerners maintained on retaining power for another four years, so that power will then move to the North for eight uninterrupted years. The National Executive Committee of Peoples Democratic Party held a meeting and votes were cast in favour of the South and power continued in the South with an understanding that after President Olusegun Obasanjo's tenure, power should return to the North for eight unbroken years. [6] At the 
expiration of President Olusegun Obasanjo's regime of eight years saw the emergence of Alahaji Umoru Musa Yaradua from the North, The power was however truncated with the sudden death of Alahaji Umoru Musa Yar 'Adua in 2010.

The question to be answered at the end of this study is, how has political corruption fared during these periods of rotational Presidency? Thus, the objective of this study is to evaluate rotational Presidency and political corruption in Nigeria during the regimes of President Obasanjo and Umoru Musa Yar' Adua which lasted between 1999 and2010.

\subsection{Rotational Presidency And The 1999 Constitution}

\section{Literature Review}

The supreme authority of any nation is the Constitution, this means that no other law should take prominence over the Constitution. Rotational Presidency is not enshrined in the 1999 Constitution, thus, rotation was a constitutional abuse. Closely related to the principle of rotation is another principle known as Federal Character, enshrined in Section 13 (3) and (4) of the constitution and it states that:

The composition of the Government of the Federation, or any of its agencies and the conduct of its affairs shall be carried out in such a manner as to reflect the federal character of Nigeria and the need to promote national unity, and also to command national loyalty, thereby ensuring that there shall be no predominance of persons from a few states or from a few ethnic or other sectional groups in that Government or in any of its agencies.[7]

The Third Schedule, Part 1 of the constitution established a special commission- The Federal Character Commission as a federal agency for the implementation of the provisions of the Federal character. It is the duty of this Commission to monitor, promote and ensure compliance to this principle by all agencies of government including Parastatals, Departments, Ministries, Police, the Armed Forces, and other Security Agencies. This principle also governs the conduct of the affairs in States and Local Government.

The Principle of Federal Character maintains that all sections of the country are represented in Government appointments and in all organs of government in Nigeria. In Nigeria today, the appointment of Federal Permanent Secretaries and Ministers are done in such a way as to ensure that all States have at least one Permanent Secretary and one Minister. This is in compliance with the Federal Character Principle and it is same with the appointment of Ambassadors or High Commissioners, Commissioners of the Revenue Mobilization and Fiscal Commission etc. This strictly speaking is a form of zoning and rotation for equitable representation among the component units of the federation.[8]

In the Constitution also, are States and Local Governments, Senatorial districts, Political Constituencies, Offices and Wards to facilitate the devolution of power to various segments of the polity. The essence is to ensure social justice and equality in the polity and to avoid the concentration of the power of representation in any one constituency be it the office of the Governor, Senate, Federal or State House. Over time this practice becomes an article of faith which binds the people together. It is like a conventional wisdom with similar intendment as the Federal Character Principle. This is not to say that the Federal Character principle has been judiciously applied in the distribution of power and the spoils of office in the country. Nigeria therefore, has all these times practiced the rotation principle which in a strict sense makes every particular legislative, gubernatorial or even presidential seat to move round different zones of Nigeria and occupied in turn by persons from these zones. [9] Zoning and rotation thus is not a novel idea, but a norm practiced over the years either as a convention or as a process of implementing the federal character principle. It is therefore an implied constitutional provision accepted by all segments of the Nigerian society.

\subsection{Rotational Presidency and the Constitution of the People's Democratic Party (PDP)}

The Peoples Democratic Party (PDP) is unarguably the largest party in Nigeria and also the ruling Party. Any issue unresolved in PDP may however have a reverberating effect on the political landscape of Nigeria. What was supposed to be an internal arrangement by the PDP is actually impacting heavily on the political evolution of Nigeria. Zoning and rotation are actually enshrined in the PDP Constitution. Article 7.2 (c ) of the Constitution states that:

In pursuance of the principle of equity, justice and fairness, the party shall adhere to the policy of rotation and zoning of party and public elective offices and it shall be enforced by the appropriate executive committee at all levels.[10]

The contending issue here is rotation and zoning. But to clearly understand the principle of the PDP Constitution, it is important to understand what a zone represents. The Constitution of the PDP recognizes Nigeria as having six (6) geo-political zones, and the PDP operates within this ambit. These are South-East, South-South, South-West, North-Central, North-East and North-West. These zones have been the basis of power sharing and political participation, especially since the 1995 Constitutional Conference. The six geopolitical zones are designed to ensure equal participation of all the segments of the country in its administration and to 
further advance the principle of Federal Character as enshrined in Section 14 (3) and (4) of the Constitution of the Federal Republic of Nigeria.[11]

The Constitution of the PDP is not emphatic on how long a zone approved by the so-called "appropriate Executive Committee" should enjoy the incumbency of a particular position under this arrangement. It is this loophole in the PDP constitution that President Olusegun Obasanjo exploited to stay eight years in office.[12] In support of the above, what this means is that while the zoning arrangement allowed Obasanjo to take his first tenure of four years, the PDP constitution did not expressly allow him to stay for the second four year term as the constitution made no such provision. [13] The principle of zoning and rotation as enshrined in that Constitution, does not expressly guarantee a second term for a person after completing his first term in office. Second term is conditional and it is predicated on performance and the will of the voters as stated in the PDP constitution:

Indeed Section 135 (2) of the Constitution states that the president shall vacate his office at the expiration of a period of four years commencing from the date when he ...took oath of Allegiance and oath of office.[14]

Second terms are not guaranteed by the party's constitution, but are only a constitutional right of an occupant of the office of the President or Governor. Section 137 (1b) of the constitution states that:

A person shall not be qualified for election to the office of the President if ...he has been elected to such office at any two previous elections. Unless therefore a person has been elected as President on two previous elections, he is qualified to contest unless impinged by other provisions of the constitution. PDP or any other political party guided by this provision in the 1999 Constitution of the Federal Republic of Nigeria (as amended) has no power to stop an Incumbent.[15]

\subsection{Political Corruption}

Corruption can be described as dishonesty or illegal behavior, especially from people in authority and it is one of the major social problems facing Nigeria. It is no more news to talk about corruption on the television, radio or even in the newspapers. The moral atmosphere in Nigeria today is conspicuously polluted and stinking. There is wide scale dishonesty in the country. Thus, political corruption is described as illegal use of powers by officials of government for their own private gains, especially when such illegality is connected to their official duties. Political corruption can come in various forms such as embezzlement of government funds, giving and taking bribes, money laundering, nepotism etc. One can safely say that corruption has been institutionalized in Nigeria. [16]

Writing on the causes of political corruption in Nigeria, some authors have discussed the different potential causes of corruption in the country, to include shift in the value orientation of our people. Communalism has replaced by individualism. These days, the welfare of the generality of the masses is almost an abomination to those in government. There is also a shift from humanism to materialism. Political office holders stress more emphasis on money making rather than meeting the expectations and needs of the generality of Nigerians given way to ostentatious living and flagrant display of wealth. Tribalism is also noted to be another major cause of corruption in Nigeria. Tribalism refers to the act of exercising strong tribal affinity to one another with the air of superiority over other tribes. [17] Claims are laid to the chord that binds them with their fellow kinsmen. That every citizen is first and for-most a member of a local community cannot be disputed. But this should not be over dramatized. This could be the case of such groups that believe they are superior to other local groups within the nation or state. This could affect the civic functions and peaceful co-existence of the nation. Tribalism has caused and still standing in the way of progress of Nigeria. A tribe always suspects the other. Some complain of marginalization. This has made it difficult for the people from different parts of the nation to work together as members of one country. Many people may see government officials that are their kinsmen as holding necessary avenues for their personal survival or gain in terms of seeking favor from those officials which may impose difficult strains on the ethical disposition of the official. [18]

It was clearly stated, while discussing some of the effects of corruption that in politics, corruption undermines democracy and lead to bad governance by flouting or even subverting formal processes.[19] Corruption in elections and in the legislature reduces accountability and distorts representation in policymaking. Rule of law is compromised under corrupt regimes and the country is not administered well leading to lack and inefficient provision of resources and services to the citizens. More generally, corruption erodes the institutional capacity of government if procedures are not followed, financial resources are embezzled, and vital positions in the country go to the highest bidder.

\subsection{Corruption AND Obasanjo's Fourth Republic}

\section{Data Analysis}

May 29, 1999 marked the inception of Obasanjo's ascension to civilian leadership of the country. President Obasanjo in his celebrated 1999 inaugural speech declared that there would be no sacred cow. 
Obasanjo in furtherance to his fight against corruption cancelled many contracts that were awarded and oil block licenses and allocation that were granted by the former head of state (Gen. Abubakar). Besides, his administration created the Independent Corrupt Practices Commission (ICPC) and the Economic and Financial Crimes Commission (EFCC). However, in spite of these measures against corrupt practices, Obasanjo and his administration became the victims of corrupt practices, Obasanjo came out of prison to contest the 1999 election and his farm situated at Ota his home town was performing at the lowest ebb. Economically, Obasanjo dwindled to a very significant extent that his properties including his farm were almost sold. In a space of eight years that Obasanjo governed Nigeria, his farm was transformed and is today rated as one of the richest in the world, this amount to corruption and abuse of office. Eight years of Obasanjo's regime created a few rich people and so much wealth coming to the hands of government out of which Nigerians received aggravated poverty and economic pain.[20]

There was a scandal that involved Obasanjo and his deputy Atiku Abubakar, on the Petroleum Technology Development Fund (PTDF) a scandal that nearly derailed the 2007 general election. In the fourth republic, the upper house (the senate) was turned into a theatre of award of dubious contracts. This necessitated many revelations in the press indicating that many of the contracts were awarded at highly inflated prices. This did not go down well with other Senators who insisted that a probe be carried out and that the senate president and his deputy should step down while the probe lasted. This gave birth to Senator Idris Kuta panel. [21]

Senator Idris Kuta's panel came out with some findings. The panel set up terms of reference that would make it easier for the panel to thoroughly look into the case. These terms of reference were:

- $\quad$ To determine the numbers of contracts awarded by the Senate in the past one year from $4^{\text {th }}$ June 1999 to $17^{\text {th }}$ July 2000.

- To identify the officers of the Senate and other Senators that participated in the exercise of contract awards.

- To identify to whom the contracts were awarded, for what and the amounts involved.

- To determine whether laid down rules and procedure were complied with in the award of contracts

- To determine the position of the contracts whether satisfactorily completed,

- Accounting Officer of Senate referred to in the Treasury Inspection Report of the Accountant-General of the Federal forwarded to the Senate under cover of letter Ref No. BRES/134 of $29^{\text {th }}$ June 2000, signed by the President of Federal Republic of Nigeria, Commander-in-Chief, to comment on the allegation.

- To determine the role of Principal Officers of the Senate in all these contracts awards,

- To examine any other issue relevant or incidental to the investigation.

On term of reference number one, it was discovered that a total number of about 91 contracts were awarded by the Senate during the period under consideration. Term of reference number two also revealed that the following Senators participated in the award of contracts between the $4^{\text {th }}$ June, 1999 and $17^{\text {th }}$ July, 2000.

- Senate President (ex) - Senate Evan Enwerem

- Senate President (ex) - Senate Chuba Okadigbo.

- Deputy Senate President- Senator Haruna Abubakar.

- Senator A.T Ahmed- former Chairman, Senate Services Committee.

- Senator Gbenga Aluko.

Information on term of reference number 3 is contained in TABLE 1

Table 1: Information on Term of Reference Number 3.

\begin{tabular}{|c|c|c|c|c|c|}
\hline & Contractor & Senator & Amount (\#) & $\begin{array}{l}\text { Nature of } \\
\text { Contract }\end{array}$ & $\begin{array}{l}\text { Amount paid as at } \\
21 / 6 / 2000\end{array}$ \\
\hline \multirow[t]{2}{*}{1.} & Independent & Senator & $13,528,400$ & 15 Nos. Xerox & \\
\hline & Strategies Ltd. & Gbenga Aluko & & $\begin{array}{l}\text { 5815,31 Nos } \\
\text { Xerox fax / work Centre. }\end{array}$ & Fully Paid \\
\hline 2 & Associated & SenatorGbenga & $14,880,000$ & 24 Nos. & Fully Paid \\
\hline & $\begin{array}{l}\text { Logistics } \\
\text { Ltd. }\end{array}$ & Aluko & & Xerox 5815 & $\begin{array}{l}\text { Document } 2 \text {, page } 6 \\
\text { paragraph } 9 .\end{array}$ \\
\hline 3 & Labonil Nig Ltd. & Senator F. Ita Giwa & $4,506,000$ & $\begin{array}{l}5 \text { Nos Xerox } \\
581519 \text { Nos } \\
\text { Shredder Rexel } 250\end{array}$ & Fully Paid \\
\hline 4 & Labonil Nig Ltd. & Senator F. Ita Giwa & $1,062,593.40$ & $\begin{array}{l}\text { Fencing of Senator F. Ita } \\
\text { Giwa's residence }\end{array}$ & Fully Paid \\
\hline 5 & Exclusive Int'1 Ltd & $\begin{array}{l}\text { Ararumel (His } \\
\text { wife and Children) }\end{array}$ & $3,738,525$ & $\begin{array}{l}\text { FurnishingofSenate } \\
\text { President's Office Annex. }\end{array}$ & Fully Paid \\
\hline 6 & Tiksa Nig Ltd & $\begin{array}{l}\text { Senator Othman } \\
\text { Idi Guda }\end{array}$ & $1,070,000$ & General Stationery & Fully Paid \\
\hline 7 & Zibagbo Nig Ltd & SenatorRoland Owie & $17,000,000$ & $\begin{array}{l}\text { Cleaning and } \\
\text { Gardening }\end{array}$ & Fully Paid \\
\hline
\end{tabular}

Source: Ugbolue,( 2000). 
It was gathered that, on term reference number 4,there were laid down rules and procedure for the award of contracts which had been in existence in the National Assembly since the Second Republic. The rules and procedure were reproduced and sent to all the Principal Officers, Senators and Honourable members by the Clerk of the National Assembly. On term of reference number 5, it was discovered by the panel that some of the contracts awarded and which were fully paid for were not executed or were abandoned completely. Also that, the management of the National Assembly did nothing to the contractors to complete their projects. With respect to term of reference number 7 that is, the determination of the role of Principal officers of the Senate in all the contracts, the findings of the panel showed that, the former Senate President (Senator Evan Enwerem) from 4th June 1999 to 18th November 1999 awarded 3 contracts.

The first one was on $31^{\text {st }}$ August 1999 to a Peak Design Associates which was to supply 10 No. IBM Typewriters, 5 No T200 Refrigerator and 5 Nos. Shredding machine for Senate which amounted to \#2,064,800. The second contract was awarded on the same day as above to a contractor Task System Ltd which was to supply 3 Nos. Computer set for the office of the Senate President which amounted to \#1,650,000. The third contract was also awarded in the same date as above to a contractor Smart Science Ltd which was to supply 1 No. computer set, 1 No. Scanner, 1 No. IBM typewriter, 2. Nos. T200 Refrigerator, 3 Nos. Shredding Machine, 3 Nos. Radio, 1 No. Sharp Copier for the office of the Senate President totalling \#1,285,200.

For Senate Chuba Okadigbo, the panel found out that he granted many anticipatory approvals to many contracts and that such anticipatory approvals were accompanied by approvals for payment of between 50 percent and $100 \%$ of the contract sum before seeking ratifications which prescribed a maximum of $25 \%$ payment in such cases. The Deputy Senate President, Senator Haruna Abubakar approved Welfare Packages of \#16,950,000 for himself and \#22.95m for the Senate President. Senator Gbenga Aluko acted as the Sole Administrator of the Senate Service Committee between $30^{\text {th }}$ November 1999 and $15^{\text {th }}$ February 2000 . He was also responsible to the Senate President in the awards of contracts. Other Principal Officers who attended the meeting of the $21^{\text {st }}$ June 2000 leading to the ratification of the contracts included Senators Okadigbo, Haruna Abubakar, Mojisoluwa Akinfenwa and Abubakar Girei.

The findings of the panel also revealed that laid down procedures and rules were not complied with in the award of all the recognised contracts in the National Assembly. The panel also investigated other related issues and in this case, it was the purchase of 117 cars bought for the National Assembly. Investigation revealed that, 117 cars were bought in two phases - 51 Peugeot (505) and 66 Peugeot (505) but the defunct Senate Services Committee contravened the Federal Government directives that official cars should be purchased directly from the manufacturer (PAN) and not from elsewhere and because of this contravention, cost differences of \#2,615,250 and \#18,394,098 were incurred in the first and second batches of vehicle procurement respectively.

Beyond these, there were other revelations which were not contained in table 1 above. Senator Chuba Okadigbo the erstwhile Senate President was alleged to have received the sum of \#22.95 million for Sallah/Christmas without questioning. He was also found guilty by the Kuta panel of inflating \#173million street light project which he did not deny before the panel. Again, he received the sum of \#32million for the purchase of 8 additional cars bringing to 32 cars earmarked to his office. He received the sum of \#37,211,570 for furnishing of the Senate President's residence which was above the Senate approved \#25million, over \#5million for security gadgets in the Senate President's residence without authorisation and lastly, the installation and commissioning of 100KVA generator for the Senate President's residence at an inflated rate price of \#15million without authorisation. Senator Haruna Abubakar the then Deputy Senate President was indicted along with the Senate President for receiving the welfare package of \#22.95million. [22]

Senator Bala Adamu was found guilty of not being able to account properly for \#10million released by the Senate for the purchase of relief materials to riot victims in Kaduna. Senator Abubakar Girei was found guilty of collecting \#6.2million to purchase Sallah gifts for the Senators in which most of the items were overpriced. Aside, those civil servants who were involved in corrupt practices had their cases referred to the Head of the Federal Civil Service while Senators found guilty were told to refund some amount of money. In all, these punishments did not commensurate with the gravity of the various offences committed.

\subsection{Yar'Adua's Administration And Corruption In Nigeria.}

That corruption persisted and that some personalities were mentioned in connection with corrupt practices under Yar'Adua's administration (2007 - 2010), were well known to President Yar' Adua himself, as he declared:

I promise this nation that once we have a response, those names in response will be made public and we will take action and direct that the names should be forwarded to the EFCC and those officials and former officials involved will be arrested and prosecuted.[23]

The fact under this administration remains that, the President Yar'Adua could not march his words with action. The entire administrations became riddled with corrupt practices. Barely three months when 
President Yar'Adua was sworn in, there were publication on the pages of Nigerian newspapers that contracts were awarded for the renovation and furnishing of official residences of the Speaker and the Deputy Speaker as well as the purchase of 12 Vehicles for principal officers at \#628 million an amount which was later corrected by the Senate President, David Mark as \#579 million. [24]

This necessitated the setting up of a nine-man independent ad-hoc committee to look into the case. The committee's terms of reference were to:

- Examine the award of contracts for the upgrading of the official residences of the Speaker and the Deputy Speaker, and

- Examine the contracts for the purchase of official and utility vehicles for the leadership of the House, and to report to the House within two weeks.

The ad-hoc committee however concluded that due process was not completely followed in the awards of the contracts based on the following facts:

- The tender was not advertised;

- No in house Bill of quantities and drawings (architectural, structural, electrical and mechanical) such as there was no basis for arriving at the approved contract;

- No specific budgetary provision for renovation and furnishing of the official residences of the Speaker and Deputy Speaker in the 2007 Budget;

- No specific budgetary provision for the purchase of vehicles for principal officers in the 2007 budget;

- The procedure for the award by the Body of Principal Officers on the July 12, 2007 shows major act of omission and disregard for laid down procedure;

- The memoranda for the award of contracts presented at the meeting of the body of Principal Officers of July 12, 2007 were revised before some of the quotations for the jobs were processed;

- Some of the companies that sent quotations were not registered with Corporate Affairs Commission. They therefore lacked capacity to compete for the contracts in questions since the law does not recognise them as persons;

- It appears that some principal officers were excluded from the meeting of July 12,2007 by not serving them notice for the meeting particularly the Minority Leadership;

- The contract sum of $\# 238,856,152$ in respect of the renovation and furnishing of the residence of the Speaker was for the maintenance and not inclusive of cluster of structures in the compound and

- All quotations relating to the renovation and furnishing contracts directed to the office of the Clerk to the National Assembly were first acted upon by the Hon. Speaker for the attention of the Clerk to the National Assembly directing him to process (Reports of the Committee).

However, for the Senate President David Mark to have described the allegations of financial misconduct against the Speaker and her Deputy as being without merit is far from the truth and such declaration should be seen as a ploy to cover up the misdemeanour.

In another development, there was a scandalous purchase of 380 Peugeot 407 cars from Peugeot Automobiles Nigeria (PAN) Ltd by the House of Representatives with some principal officers indicted. This was investigated by the Economic and Financial Crimes Commission (EFCC) and in a 14-page report dated February 20, 2009, being addressed and forwarded to the then President, Alhaji Umaru Musa Yar'Adua, the EFCC stated that some officers and members of the House of Representatives actually had questions to answer in respect of the alleged scam in the purchase of 380 Peugeot 407 cars from PAN. [25]

In order to find out the truth, the EFCC sent its team leading to discussion being held with the Speaker of the House of Representatives (Hon. Dimeji Bankole), and the Deputy Speaker (Hon. Nafada). The Commission also recorded Statements from the then Clerk of the National Assembly, Mr. Nasiru Ibrahim Arab, and the Acting Clerk of the House, Mr. Niyi Ajibode. It also recorded statement from the National Assembly's Director, Estate and Works, Idris Muhammad Ataba Sani- Omolari, Planning and Legislative Budget, Muhammed Kabir Suleiman, and Ag. Director, Finance and Supplies, Bukoye Lasisi. Also, the agency visited PAN, Kaduna from where various documents were recovered and wrote to several banks and other establishments including the Code of Conduct Bureau and the Corporate Affairs Commission.

The conclusion reached by the EFCC after a thorough investigation showed that:

- there was a contract between the House of Representatives and Peugeot Automobile Nigeria (PAN) Ltd which occasioned the payment of the sum of $\# 2,359,486,500$,

- the sum of \#414,171,920 was transferred from the PAN account in Zenith Bank to ASD Motors account in the Same bank, 
- the account officer in charge of verification of all payment vouchers of contract awarded by the House of Representatives, Mrs Bolanle Iyomere, stated she did not sign the vouchers for the payments of the 380 units of the Peugeot 407 supplied to the National Assembly. [26]

Still on Corrupt practices during President Yar'Adua's regime, it was in the reversal of the war against corruption that the Yar'Adua administration did the most damage to its credibility with Nigerians and the international community. [27] The systematic destruction of the EFCC by the Yar'Adua administration began as soon as James Ibori - former governor of Delta State (Ally and financier of Yar'Adua), was charged for money laundering and corruption at the Federal High Court in December 2007. Ibori and his two wives were facing similar charges in UK courts. A quick succession of events led to the extra-legal removal, demotion, and dismissal of the EFCC's respected chairman - Nuhu Ribadu, and the deployment of all the investigating EFCC staff trained by the FBI and London Metropolitan Police. Two attempts were made on Ribadu's life and he went on exile as a visiting fellow at Oxford University, UK and Center for Global Development, USA. In a detailed interview with Ribadu, he recounted his experience, concluding that "when you fight corruption, it fights back".

Since the firing of Ribadu, all the case files on the so-called 31 corrupt governors disappeared or declared non-existent by Farida Waziri, his successor at EFCC. The cases already in court were withdrawn, delayed or settled in what many consider dodgy plea-bargains, like Igbenidion's. Other well-known cases of corruption that the administration blatantly refused to prosecute include bribery payments by Willbros - an oil services company, corruption involving Siemens - a German engineering company (in which senior PDP leaders collected $\$ 10$ million in bribes) and the well-known Halliburton/KBR case in which $\$ 180$ million were pocketed by various officials. [28]

Also associated with corrupt practices were the allegations of financial misuse against the Speaker of the House of Representatives, Dimeji Bankole and the leadership of the House raised by the "Progressives" This allegation turned the entire House into a battle ground in which eleven members that constituted the "Progressives" were suspended by the Speaker of the House of Representatives in order to cover up the alleged scandal.

\section{Conclusion}

The study revealed that political corruption was not reduced by rotational Presidency because Nigeria's democracy especially the one that commenced from May 29, 1999 was born with persistent political corruption. Thus, a statistical index on 85 countries, covering all the continents of the world from Transparency International showed that, Nigeria and Tanzania occupied the fifth position. While this was so in 1999, by 2004 the same Transparency International ranked Nigeria as the third most corrupt country in the world. Both internal and international observers have rated Nigeria as the most corrupt country in the world, deserving a pride of place in the Guinness Book of Records. Nuhu Ribadu, a former head of the Economic and Financial Crime Commission (EFCC) alerted the nation that as many as 31 former governors out of 36 have a case to answer on corruption. The issue is so appalling in Nigeria that in another development, Ribadu revealed how politicians siphoned over \$10bn from Nigeria monthly. [29]

Thus, a lot need to be done by the anti-corruption agencies like the Economic and Financial Crime Commission (EFCC) and the Independent and Corrupt Practices Commission (ICPC). They should intensify their efforts and do their jobs without fear or favour, and people of proven integrity should always be transparently appointed at the helm of affairs of these commissions, so as to instill sanity among political elites in other to reduce political corruption in Nigeria. There should be no interference in the activities of these commissions by the government of the day.

\section{References}

[1]. G. Okwenna, Power sharing revisited rotational Presidency zoning Federal character and multiple Vice Presidency in Nigeria, www.mtladen.hlogspot.com 8/82011, 2011, p.1

[2]. O. Agagu, (2004). Rotation and power struggle in Nigeria International Journal of Development and Sustainability Vol.1 No.2, 2012: 452-459

[3]. U. Njoku, U. Between rotational Presidency and inventing the structures of social justice, www.kenu.com/publication, 2005 , p. 1.

[4]. W. Idowu, "Ethnicity, ethnicism and citizenship: A philosophical reflection on the African experience, Journal of Social Science vol. 8, No 1, 2004 pp 45-58

[5]. O. Gbolahon Jonathan, zoning and the press This Day September $10^{\text {th }} 2011, \mathrm{p} 12$.

[6]. E.Clarke, 'Crisis of Presidential rotation This Day September $14^{\text {th }} 2008$, p. 18.

[7]. B. Bakpo, It is time North supported the S-S Presidency Nigerian Tribune August $25^{\text {th }} 2010$, p 41 .

[8]. O. Eneje, The truth about PDP rotation and zoning policy" This Day September 19 ${ }^{\mathrm{tH}} 2010$, p 12.

[9]. C. Okebugwu, The essential ingredients of rotational Presidency \& power sharing strategy" www. nigerdeltacongress. com/article, 2011, p 1 .

[10]. B. Bamidele, Rotational Presidency classic contribution to democracy www.nigerianvijlagesquare.com 2011

[11]. E. Okolo, Constitutional review and single five-year term for elected officers, The Guardian Thursday September 22 ${ }^{\text {nd }} 2011$, pp $8-9$, O. Fagae, Nigeria and the global corruption index, The Guardian, November 2, 2009, p.16.

[12]. L. Okonkwo, Nigeria in search of sustainable democracy, Foreign Affairs Spring vol. 62 part 2. 2010 , pp. $905-927$.

DOI: 10.9790/0837-191255057 www.iosrjournals.org $\quad$ 56|Page


[13]. W. Ikokwu, Much ado over zoning Daily Sun July $7^{\text {th }} 2010$ p 19.

[14]. F. Osadebe Confab and rotational Presidency Nigerian Tribune June $29^{\text {th }} 2010, p 5$.

[15]. O. Nwosu, Methodology of teaching Christian religious studies and moral education, (Nsukka, Paschal Communications, 2009)

[16]. O. Nwosu, Methodology of Teaching Christian Religious Studies and Moral Education, (Nsukka, Paschal Communications, 2009)

[17]. R. Wraith, and E. Simpkins, Corruption in developing countries: Tribalism might as well remain the greatest obstacle to tackling official corruption in Nigeria. The Journal of Modern African Affairs, 1983

[18]. Wikipedia,The free encyclopedia, Political Corruption, 2013.

[19]. T. Okwezuzu, Daily Times Nigeria January 11, 2013,https//www.facebook.com/dailytimesng/posts/442063062515404

[20]. U. A. Nwobi, Rotational Presidency and democracy in Nigeria 1999-2007, doctoral seminar, University of Nigeria, Nsukka, 2011.

[21]. H. Ugbolue, H. The fall of Okadigbo, The News August 14, 2000.

[22]. M Oloja, Yar'Adua speaks, vows to break corruption, power jinx" The Guardian, April 27, 2009.

[23]. M. Jimoh, A. Ogbodo and O. Agbana Assembly, Mark clears Etteh's deputy over alleged scam”, The Guardian September 3, 2007.

[24]. Jimoh,, M. (2010), Why lawmakers turned chambers into brawling circus, The Guardian, June 24.

[25]. M. Jimoh, Why lawmakers turned chambers into brawling circus, The Guardian, June 24, 2010.

[26]. T. Ogudo http://www.crisisgroup.org/home/index.cfm?id=6080\&l=1 accessed 04/30/10, 2010

[27]. T. Ogudo (2010). http://www.crisisgroup.org/home/index.cfm?id=6080\&l=1 accessed 04/30/10, 2010.

[28]. O. Farotimi, Over $\$ 10$ bn freighted from Nigeria monthly” Daily Sun, July 21, 2010. 